\title{
Comparative evaluation of the effect of Nigella sativa extracts and nystatin as a traditional drug on Candida albicans in the primary school students in Mosul and Tikrit cities.
}

\author{
Maymona K.Yahya*; Abdul_Rahman A. Altae**. \\ *Department of clinical Laboratory Sciences, College of Pharmacy, University of Mosul. \\ ** Department of Microbiology, College of Medicine, University of Tikrit.
}

\begin{abstract}
$\underline{\text { Received }}$
20.5.2012

Accepted

$\overline{16.5 .2013}$
\end{abstract}

\section{ABSTRACT}

Objectives: To detect and compare the inhibitory effect of Nigella sativa extracts and compare their effects with traditional drugs on Candida albicans.

Introduction: The developing microbial resistance to the existing anti-microbial agents has become a real challenge and a serious problem. Seeds of Nigella sativa have been used for a long time in folk medicine for the treatment of such infections. Production of new potent agents is urgently needed, especially for hospitals and health centers. Therefore, the antifungal effect of aqueous and alcoholic extracts of the seeds against Candida albicans from primary school students were investigated.

Materials and Methods: The in vitro antifungal effect of the extracts at a concentration of (10, $15,20,25,30,35,40) \mathrm{mg} / \mathrm{ml}$ on C. albicans isolated was assessed and compared with traditional drug, nystatin using agar diffusion assay.

Results: The aqueous extract did not show any inhibitory effect against the isolated Candida. The alcoholic extract indicated significant inhibitory effect. nystatin show inhibitory effect higher than alcoholic extract at a concentration $40 \mathrm{mg} / \mathrm{ml}$.

Discussion: The results of this study revealed clear potentiality of $N$. sativa as a source for antifungal drugs and support its use in folk medicine for the treatment of fungal intestinal infections. This finding warrants necessity of further investigation of this product of folk medicine.

Keywords: Nigella sativa extracts, nystatin, Candida albicans.

الخلاصة

اهداف البحث: صممت الدراسة للكثثف عن التأثير التثبيطي لمستخلصات الحبة السوداء ومقارنتها مع الادوية الثنائعة الاستعمال

ضد الفطر Candida albicans.

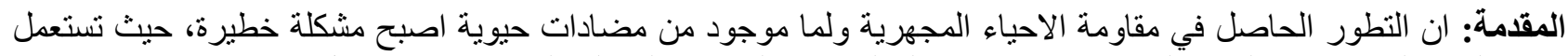

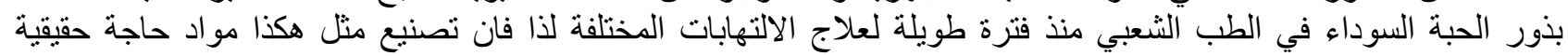
خصوصا في المستشفيات و المر اكز الصحية.

المواد وطريقة العمل: استعملنا عدة تر اكيز من مستخلصات الحبة السوداء المائي و الكحولي (40،35،30،25،20،15، 10، 10)ملغم /مل

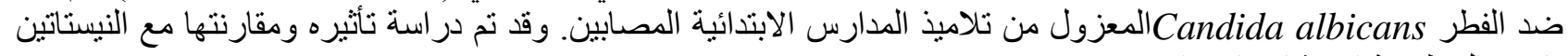
باستعمال طريقة الانتشار بالاقر اص.

النتائج: بينت النتائج أن المستخلص المائي ليس له تأثير تثثيطي، أما المستخلص الكحولي له تأثير معنوي في تثثيط الفطر.

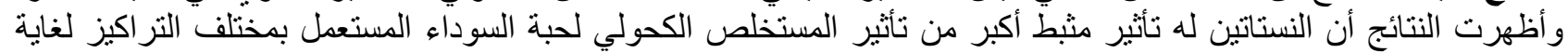
تركيز 40 ملغم/ مل.

الاستتتاج: اثتتت الدر اسة ان الحبة السوداء مصدر اللادوية المضادة للفطريات وكذللك في الطب البديل لعلاج الالتهابات المعوية الفطرية 
$\mathrm{T}$ The developing microbial resistance to the existing anti-microbial agents has become a real challenge and a serious problem ${ }^{1}$. Nigella sativa (N.sativa) is an annual flowering plant, native to southwest Asia. Among the promising medicinal plants, $N$. sativa, a dicotyledonous of the Ranunculaceae family, is an amazing herb with a rich historical and religious back ground ${ }^{2,3,4}$. Nigella sativa is found in southern Europe, northern Africa and Asia minor. The use of plants as medicines dates from the earliest years of mans evolution. Medicinal plants serve as therapeutic alternatives, safer choices, or in some cases, as the only effective treatment ${ }^{3}$.

In Islam, it is regarded as one of the greatest forms of healing medicine available. Its most famous for the saying of the holy prophet Muhammad (peace be upon him) "Hold on to use of the black seed, for it has a remedy for every illness except death". The word "hold on to" indicate a long term use ${ }^{5}$.

Nigella is known as kalonji (Hindi), habbat Al-barakah or habbat Al-Sauda (Arabic), kalvanji (urdu), siyah daneh (Persian). In English language or in the west, it is called fennel flower or sometimes just referred to as Nigella or black seed or black cumin or black caraway ${ }^{2,6,7}$. Seeds of $N$. sativa are frequently used in folk medicine in the Middle East and some Asian countries for the promotion of good health and treatment of many ailments ${ }^{4}$. Recently, many biological activities of $N$. sativa extracts have been reported, including antifungal, antibacterial, antiparasitic, and antiviral ${ }^{8}$. It has been reported that $N$. sativa seeds or its extracts have anti-inflammatory ${ }^{9}$ and antimicrobial property ${ }^{1}$.

In most healthy people, Candida albicans was a harmless micro flora but, in immunocompromised patients, develops into an opportunistic pathogen that can cause life threatening disseminated infection ${ }^{10}$. Overgrowth of Candida albicans in the intestines is responsible for a yeast syndrome that results in symptoms such as fatigue, diarrhea, constipation, rectal itching, inflammatory bowel disease (IBD), food sensitivity, headache, mood swings, sinus congestion, depression, poor memory and concentration, and cravings for sweets.

Typical antifungal drugs that used in some cases of Candida infection such as nystatin, and azoles derivatives as Fluconazole and
Ketoconazole. nystatin is first choice and the most important antifungal that used to treat gastrointestinal tract infected with Candida albicans, because it is not absorbed throughout the GIT and so typical effect will occur, but the development of resistance and the presence of adverse effects of these drugs are an emerging trend that may threaten their effectiveness ${ }^{11}$.

\section{Materials and Methods :}

\section{Nigella sativa: ( Seed Viability Test ):}

The seeds were purchased from a local herb shop in Iraq. There were identified, cleaned to remove any debris, air dried and cultured in a petridishe having wet clean filter paper or gauze and incubated at $(25 \pm 1){ }^{\circ} \mathrm{C}$ in dark growth chamber for few days. The filter paper were always kept wet by adding enough water to moisten the paper but pour out any extra water and then calculated the percentage of growth $\%{ }^{12}$.

\section{Preparation and Sterilization of Black Seed Extracts (Aqueous Extracts ):}

Aqueous extracts of Nigella sativa can be prepared depending on Riose route by dissolving $40 \mathrm{~g}$ of seeds (after cleaning it from debris) in 160 $\mathrm{ml}$ of sterile distill water in ratio 1:4 (wt:vol) by using electrical blender inside cool place to prevent losing of volatile oil, for about 1 hour then leaves at $4^{\circ} \mathrm{C}$ for 24 hour (in refrigerator). The extract were filtered by using many layers of gauze and centrifuged at $3000 \mathrm{rpm}$ for $5 \mathrm{~min}$ then filtered by wattman filter paper No.1. The extract were dried by using lyophilizor that dried by cooling under low vacuum ${ }^{13}$. The dried extract were stored at $4^{\circ} \mathrm{c}$ until using.

Aqueous extracts can be sterile by using Membrane Filter $0.45 \mathrm{u}$, that is make by dissolving $1 \mathrm{~g}$ of dried aqueous extract in $5 \mathrm{ml}$ of sterile distil water, so we have $200 \mathrm{mg} / \mathrm{ml}$ extract concentrations as crude concentration, this extracts will be sterilized by filtering through Membrane Filter 0.45u (GEMA MEDICAL S.L. .Spain)to prevent passage of microbe through it and make this concentration as a crude, from it we can prepare other concentrations which using in research

\section{Alcoholic Extracts:}

Nigella sativa alcoholic extract can be prepared depending on Grand route by crushing $20 \mathrm{~g}$ of the seeds(after cleaning it from debris) and dissolving it in $200 \mathrm{ml}$ of $95 \%$ ethanol as in ratio 1:10 (w:v) 
inside a cool place inside by using blender for about 1 hour, then put the mixture in refrigerator at $4^{\circ} \mathrm{c}$ for 24 hour . The extract were filtered using many layers of gauze then centrifuged at 3000 $\mathrm{rpm}$ for $5 \mathrm{~min}$ and the filtrate were filtered through wattman filter paper no.1. The alcoholic filtrate was evaporated using rotary vacuum evaporator (Rota vapor R11:BUCHI)that evaporate the solvent under low vacuum and under $40^{\circ} \mathrm{C}$ temp to prevent losing the volatile oil which is the main active ingredients present. The filtrate will be further dried by using lyophilizor which dry the filtrate by cooling under low pressure $^{14}$. The alcoholic extract were kept in refrigerator at $4{ }^{\circ} \mathrm{C}$ until further testing .

For making inhibitory experiments, we should make sterilization for extracts and preparing different concentrations by using crude concentration and that is occur by weight $1 \mathrm{~g}$ of dried alcoholic extract and dissolve it in $5 \mathrm{ml}$ of dissolvent like DEE(Diethyl Ether). then sterile the mixture by pasteurization method (heating in the water bath) under $62^{\circ} \mathrm{C}$ for 10 min.. So we prepare $200 \mathrm{mg} / \mathrm{ml}$ as a crude concentration which using for preparing other concentrations.

\section{Preparation of Different $N$. sativa Extracts Concentration:}

Different concentrations of $N$. sativa (aqueous and alcohol) extracts were prepared starting from (10, $15,20,25,30,35,40) \mathrm{mg} / \mathrm{ml}$ in sterile distil water and Diethyl ether as a diluents respectively. Whatman filter paper No. 1 was used to prepare discs by cutting the paper in a diameter equal to 6 $\mathrm{mm}$. The discs were then sterilized by autoclaving at $121^{\circ} \mathrm{C}$ for $15 \mathrm{~min}$ in tightly closed container having 10 discs. Adding $0.1 \mathrm{ml}$ of different concentrations were prepared to each container and were dried in the bio safety cabinet for 15 minute. Negative control disc were prepared using DEE and DW. Positive control disc were prepared using nystatin drug ${ }^{15}$.

\section{Preparation of Antifungal (nystatin) Discs:}

Depending on B.V.T.C.1979(Bacteriology Virology Tissue Culture ), we prepare wattman no.1 filter paper discs containing 100 I.U. of nystatin (samara) on each disc, which is equal to $0.06 \mathrm{mg} / \mathrm{disc}$ (each $1 \mathrm{mg}$ equal to 1666 I.U.). 100 IU of nystatin / disc is the international concentration that used in C. albicans sensitivity test against nystatin .By taking 1 tablet of nystatin that contain 500,000 I.U.and dissolve in $100 \mathrm{ml}$ of DW to prepare $5000 \mathrm{I} . \mathrm{U} /$ disc of nystatin suspension ,then add 50 of sterile whatmann filter paper discs about $6 \mathrm{~mm}$ in diameter to $1 \mathrm{ml}$ of the suspension, so nystatin disc on conc. of 100 I.U. / disc were prepared which is the desired conc. All the experiment should occur in sterile condition ${ }^{16}$.

\section{Collection of samples:}

Stool samples were collected from students of primary schools: (Al-Arqam primary school for boys, Al-hady primary school for girls, and AlArpachia primary school for boys and girls) of about 6-12 years old. Stools were taken from students in a clean water-proof with a tight fitting container $10 \mathrm{ml}$ saline as a transport medium ${ }^{17}$. The containers were labeled with patient's full name, age, sex and time of collection. Samples were examined in the laboratory within $24 \mathrm{hrs}$ of collection. Each samples was transported at $37^{\circ} \mathrm{C}$ and examined directly under the microscope for yeast cell. By taking about $1 \mathrm{gm}$ of the stool of each samples and cultured on nutrient broth and on sterile petridish containing Sabouraud dextrose agar (SDA) (having chloramphenicol and gentamicin as antibiotic to prevent contamination). C. albicans appears as large, round, white or cream colonies on agar plate . Further tests can be done for identifying $C$. albicans such as gram stain, germ tube (GT ) formation in animal or human serum ${ }^{18}$ and growth in corn meal agar (CMA) that form chlamydospore and pseudomycelium ${ }^{19,20}$.

\section{Inhibitory Effect of Aqueous Extract of Nigella sativa on Candida albicans:}

To detect the inhibitory effect of aqueous extract of $N$. sativa on C. albicans using disc diffusion method by preparing different concentration of about $10,15,20,25,30,35,40 \mathrm{mg} / \mathrm{ml}$ from the crude concentration after sterilization using sterile distiled water as a diluents ${ }^{6,7}$.

Inoculums were prepared using nutrient broth with 3-5 colonies of $C$. albicans from SDA. The inoculums were incubated at $37^{\circ} \mathrm{C}$ for 24 hours to get a suspension of about $415 \times 10^{5}$ cell $/ \mathrm{ml}$ by using a chamber. SDA were cultured with 
an inoculums of $C$. albicans using sterile cotton swabs that diffuse $0.1 \mathrm{ml}$ of the $C$. albicans suspension on the surface of the agar. Whatmann no. 1 paper discs impregnated with different N.sativa aqueous extract conc. were carefully placed on the seeded plate and adding a negative control (disc impregnated in sterile D. W. only )in three repeated petridishs. The plates were incubated at $37 \pm 1^{\circ} \mathrm{C}$ and examined for zones of inhibition after 24 hours $^{21}$.

\section{Inhibitory Effect of Alcoholic Extract of Nigella sativa on Candida albicans:}

To detect the inhibitory effect of alcoholic extract of $N$. sativa on C. albicans using disc diffusion method by preparing different concentration of about $(10,15,20,25,30,35,40) \mathrm{mg} / \mathrm{ml}$ from the crude conc. after sterilization (using DEE as a diluents ) by dipping 10 sterile filter paper discs in $0.1 \mathrm{ml}$ of each conc. of the extract ${ }^{6,7}$.

Inoculums were prepared using nutrient broth with 3-5 colonies of C. albicans from SDA. The inoculums were incubated at $37^{\circ} \mathrm{C}$ for 24 hours to get a suspension of about $415 \times 10^{5}$ cell $/ \mathrm{ml}$ by using a chamber. SDA were cultured with an inoculums of $C$. albicans using sterile cotton swabs that diffuse $0.1 \mathrm{ml}$ of the C. albicans suspension on the surface of the agar. Whatmann no. 1 paper discs impregnated with different $N$. sativa Alcoholic extract conc. were carefully placed on the seeded plate and adding a negative control (discs impregnated in sterile D. W. and DEE )in three repeated petridishes. The plates were incubated at $37 \pm 1^{\circ} \mathrm{C}$ and examined for zones of inhibition after 24 hours $^{2}$.

\section{Results:}

\section{Seed Viability Test:}

Nigella sativa seed were purchased from a local herb shop in Iraq. Three samples were taken with different viability $67 \%, 93 \%$, and $95 \%$, depending on the source of purchasing and storage environment. The favourable one is the highest viability test

\section{Extraction and Sterilization of Nigella sativa:}

$N$. sativa alcoholic extract was in liquid form due to the presence of large amount of oil in the extract and appeared brown in colour. While aqueous extract of $N$. sativa was in gelatinous form, dark brown in colour, After lyophilization, it was not converted to powder form due to the presence of oil in the extract that aid to make the extract in high viscous gelatinous form.

\section{Isolation and Identification of Candida albican:}

Candida albicans isolated from 252 stool samples which appear as yeast cell that is small round form as present in Figure $(1,2,3)$.

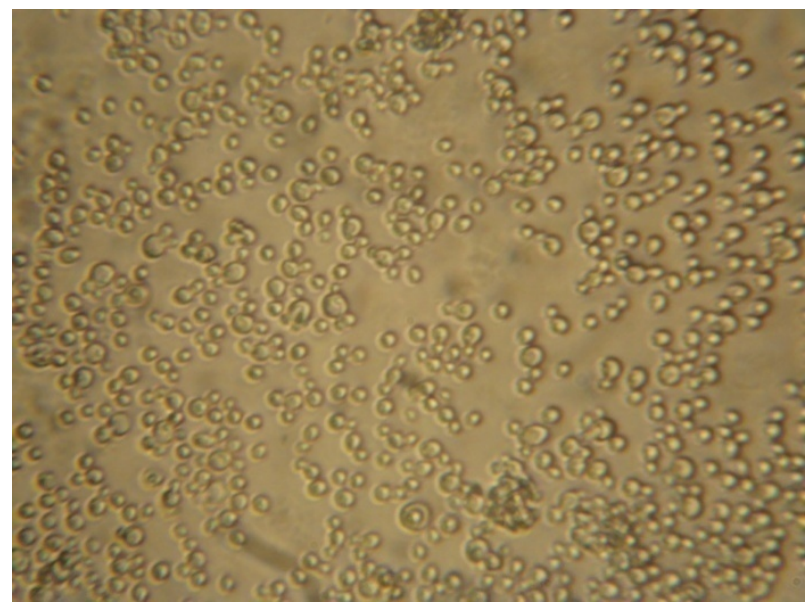


Figure (1)Candida albicans in a characteristic yeast cell with budding appeared on nutrient broth (40X).

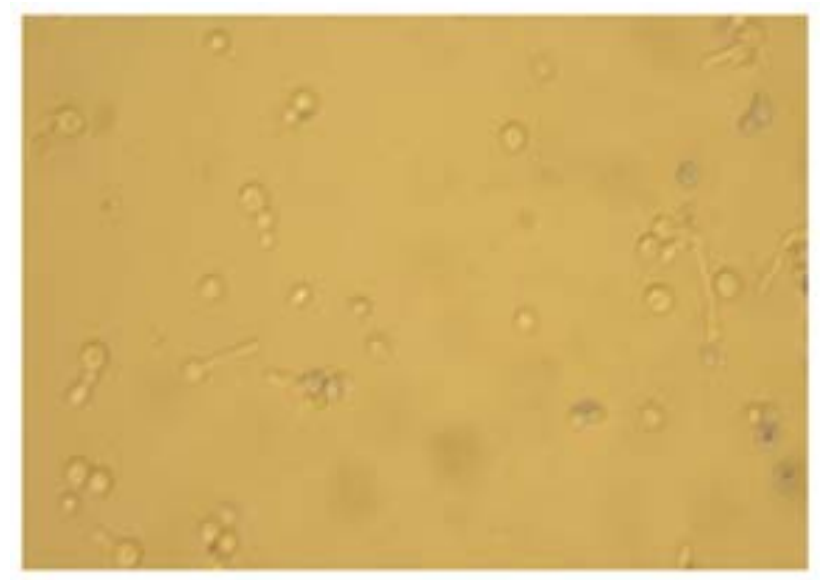

Figure (2): Candida albicans germ tube on serum at $37{ }^{\circ} \mathrm{C}$ for 2 hours(40X).

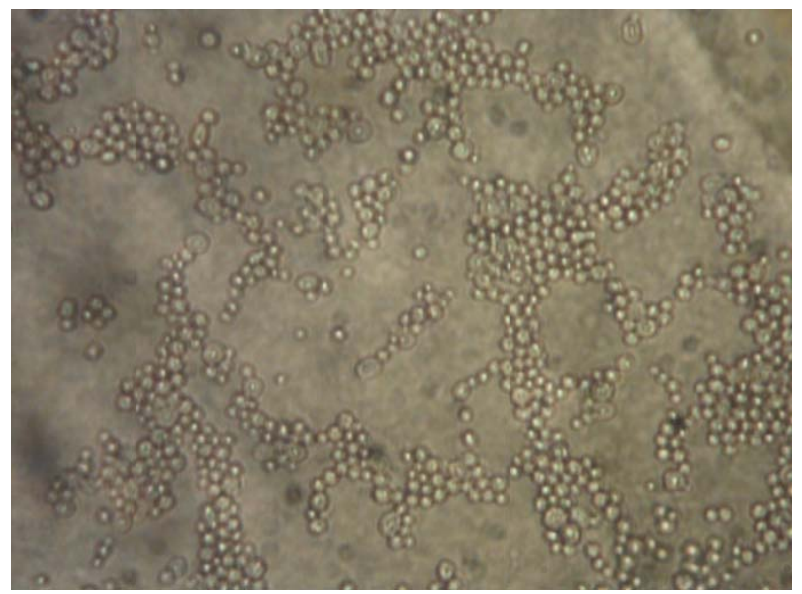

Figure (3):Candida albicans chlamydospore on CMA at $27{ }^{\circ} \mathrm{C}$ for 48 hours(40X).

Efficacy of $N$. sativa Extract on isolated $C$.

\section{albicans:}

There were no effect of aqueous extract of $N$. sativa on C. albicans isolate, while the inhibition zone was 9 when $10 \mathrm{mg} / \mathrm{ml}$ concentration of $N$. sativa alcoholic extract was used and the inhibition zone was 17.3 when $40 \mathrm{mg} / \mathrm{ml}$ concentration of $N$. sativa alcoholic extract used. This means the increase in the concentration of alcoholic extract lead to further increase in inhibition zone as in Table (1) and Figure (4). 
Table (1): The effect of alcoholic extract of Nigella sativa and nystatin on Candida albicans isolated from stool sample.

\begin{tabular}{|c|c|c|}
\hline $\begin{array}{c}\text { Type of material } \\
\text { used }\end{array}$ & $\begin{array}{c}\text { Conc. of the } \\
\text { extract }(\mathrm{mg} / \mathrm{ml})\end{array}$ & $\begin{array}{l}\text { Average diameter of } \\
\text { the inhibition zone } \\
(\mathrm{mm})\end{array}$ \\
\hline \multirow{7}{*}{ 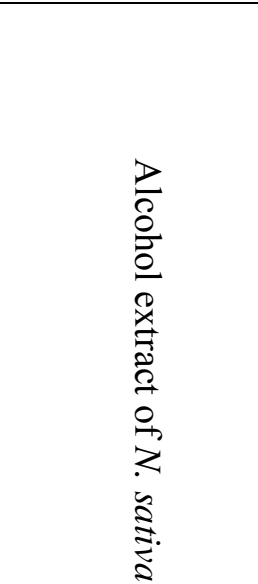 } & 10 & 9 \\
\hline & 15 & 9.8 \\
\hline & 20 & 13.1 \\
\hline & 25 & 13.7 \\
\hline & 30 & 14.3 \\
\hline & 35 & 15.3 \\
\hline & 40 & 17.3 \\
\hline Nystatin & $\begin{array}{l}100 \mathrm{IU} \\
\text { (i.e. } 0.06 \mathrm{mg} / \\
\text { disc) }\end{array}$ & 17.7 \\
\hline
\end{tabular}

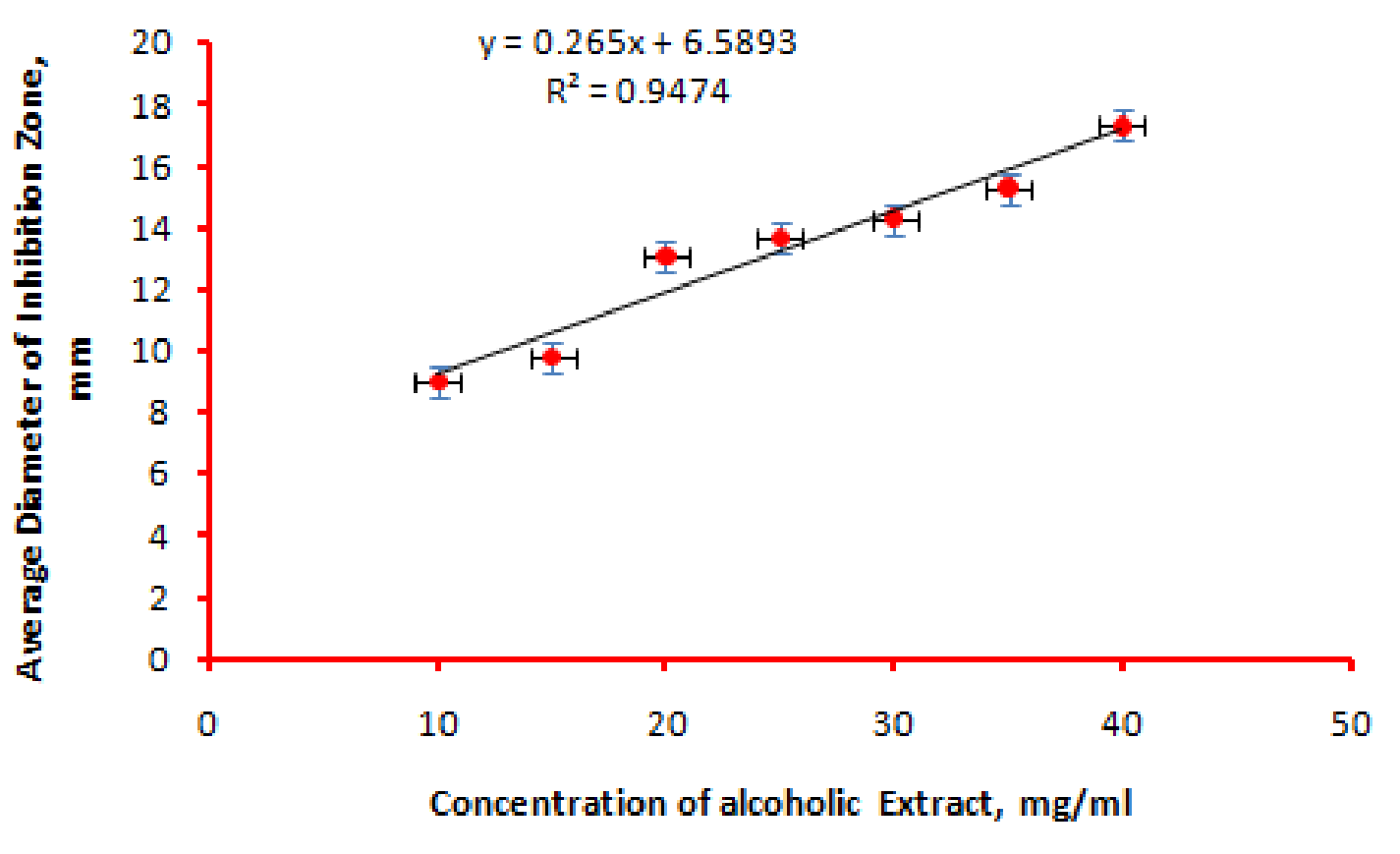

Figure (4): Comparison between the effect of alcoholic extract of Nigella sativa and nystatin on Candida albicans isolated from stool sample. 

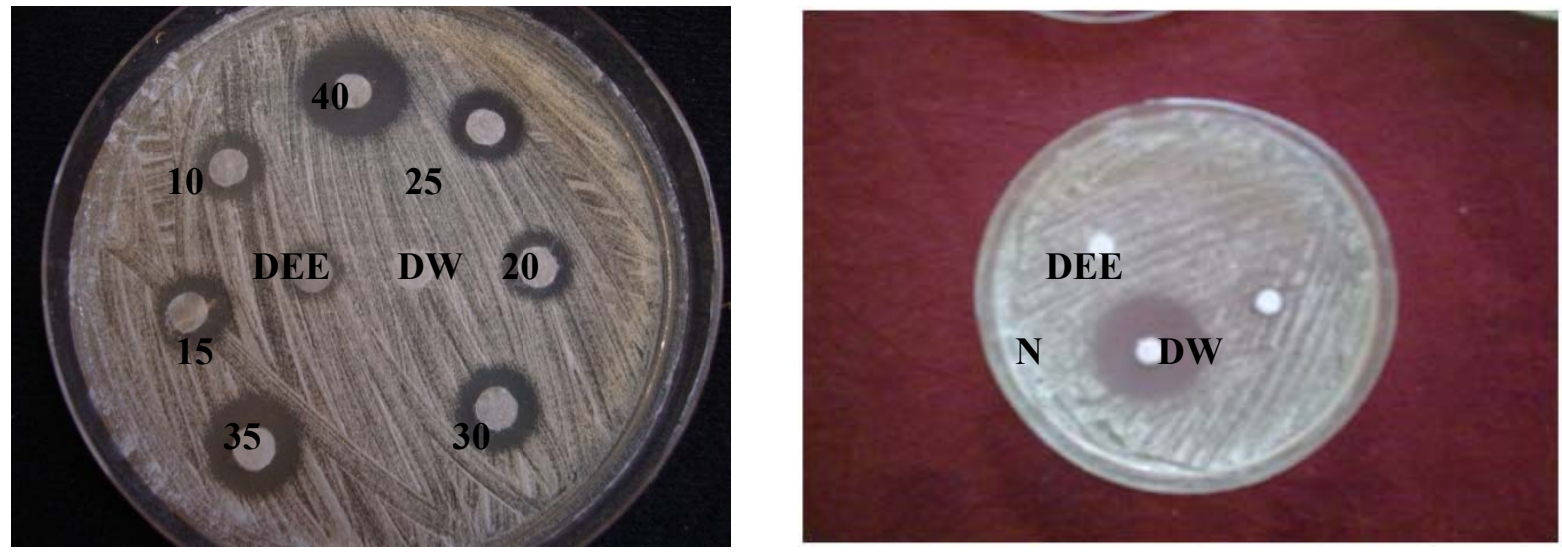

Figure (5):(a) the effect of alcoholic extract of Nigella sativa on Candida albicans isolated from stool sample.(b) comparism between the effect of nystatin and negative control(distill water and diethyl ether) on Candida albicans isolated from stool sample.

\section{Comparison Between N. sativa Extracts and nystatin on C. albicans}

The inhibition zone of nystatin disc was more than that of alcoholic extract of $N$. sativa in concentrations used of about $(10,15,20,25,30$, $35,40 \mathrm{mg} / \mathrm{ml})$. The diameter of inhibition zone of discs treated with nystatin was $17.7 \mathrm{~mm}$ when treated with $100 \mathrm{IU}$ (i.e. $0.06 \mathrm{mg} /$ disc), while the diameter of inhibition zone of discs treated with $N$. sativa alcoholic extract was $9 \mathrm{~mm}$ when treated with $10 \mathrm{mg} / \mathrm{ml}$ and increased to reach $17.3 \mathrm{~mm}$ when treated with $40 \mathrm{mg} / \mathrm{ml}$ show figure (5 a and b).

\section{Discussion:}

In the present study, Nigella sativa alcoholic extract was in liquid form due to the presence of large amount of oil in the extract and it appears brown in colour. The method of extraction in this work was depended on Grand route (22) which was modified from Verpoorte et al. ${ }^{22}$.

Nigella sativa aqueous extract was in high viscous gelatinous form. The method of extraction in this work was conducted to the procedure of El Wakil H.S. ${ }^{23}$, Al-Heali F.M, and Rahemo $\mathrm{Z}^{24}$ and Tonkal A.M.D. .

C. albicans samples were isolated from the stool of primary school students in a disposable clean dried container. C. albicans had been identified by several testing e.g. gram staining of the colonies showed large gram positive organisms suspected to be yeasts cells, formation of germ tube in animal or human serum $^{25}$ and chlamydospore and pseudomycelium in corn meal agar ${ }^{26}$.

Inhibition zone diameter of each concentration of Nigella sativa of different extract has been measured. The effect of $N$. sativa aqueous and alcoholic extract on C. albicans was estimated throughout a series of concentrations $(10,15,20,25,30,35,40 \mathrm{mg} / \mathrm{ml})$ which were used. The study found that there was week effect of aqueous extract of $N$. sativa on C. albicans isolated, but there was significant differences in the inhibitory effect of $N$. sativa alcoholic extract on C. albicans isolated from stool sample and the inhibition zone increased as the concentration of the extracts increased. The inhibition zone was 9 $\mathrm{mm}$ when $10 \mathrm{mg} / \mathrm{ml} N$. sativa alcoholic extract was used and the inhibition zone was $17.3 \mathrm{~mm}$ when $40 \mathrm{mg} / \mathrm{ml}$ used. The study illustrated that $40 \mathrm{mg} / \mathrm{ml}$ had biggest inhibition zone while the concentration $10 \mathrm{mg} / \mathrm{ml}$ had the smallest effect as in table (1) and figure (4).

Absence of effect of aqueous extract was agreed with Abu-Al-Basal 2009 ${ }^{1}$, while disagreed 
with Hanafy and Hatem $1991^{27}$ and Al-Assaaf $2008^{21}$. The presence of inhibitory effect of alcoholic extract was agreed with Hanafy and Hatem $1991^{27}$ and Al-Assaaf 2008 ${ }^{21}$, while disagreed with Abu -Al-Basal $2009^{1}$.

To comparison between the inhibitory effect of $N$. sativa alcoholic extract and nystatin on Candida albicans isolate presented in table (1) and figure (5). The inhibition zone of nystatin disc were more than that of alcoholic extract of $N$. sativa in concentrations used of about $(10,15,20$, $25,30,35,40 \mathrm{mg} / \mathrm{ml}$ ). The diameter of inhibition zone of discs treated with nystatin was $17.7 \mathrm{~mm}$ when treated with $100 \mathrm{IU}$ (i.e. $0.06 \mathrm{mg} /$ disc), while the diameter of inhibition zone of discs treated with $N$. sativa alcoholic extract was $9 \mathrm{~mm}$ when treated with $10 \mathrm{mg} / \mathrm{ml}$ and increased to reach $17.3 \mathrm{~mm}$ when treated with $40 \mathrm{mg} / \mathrm{ml}$. It had been indicated that the effect of nystatin on Candida albicans isolated were higher than that of Nigella sativa on concentration $40 \mathrm{mg} / \mathrm{ml}$. So increasing the concentration may lead to higher effect than that of nystatin. Further study should be performed on this line is needed.

$N$. sativa extracts were proved to have an immunomodulatory effect..as they have a prominent stimulatory effect on $\mathrm{CD} 4$ positive $\mathrm{T}$ cells and macrophages causing an immunomodulatory effect both in humans and animals $^{28}$. However, their exact mechanism of action on the individual components of the immune system needs to be deeply investigated. Understanding of such mechanisms will put a great impact on the management of many infectious as well as immunological disorders.

\section{References:}

1. Abu-Al-Basal MA. In vitro and in vivo antimicrobial effects of Nigella sativa linn. seed extracts against clinical isolates from skin wound infections. American Journal of Applied Sciences , 2009;6 (8): 1440-1447.

2. Zuridah H, Fairuz ARM, Zakri AHZ, and Rahim MNA. In vitro antimicrobial activity of Nigella sativa against Staphyllococcus aureus, Pseudomonas aeruginosa, Klebsiella pneumonia, Escherichia coli and Bacillus ceres. Asian Journal of Plant Sciences 2008;7(3):331-333.

3. Mohammad, M. A., Mohammad, M. M. J., and Dradka, H., Effect of Black Seed
(Nigella sativa) on Spermatogenesis and Fertility of Male Albino Rats. Research Journal of Medicinal Sciences, 2009;4(2):386-390.

4. Perveen T, Haider S, Kanwal S, and Haleen DG. Repeated administration of Nigella sativa decreases 5-HT turnover and produces anxiolytic effects in rats. Pak. J. Pharm. Sci., 2009; (2):139-144.

5. Abu-Zinadah, OA. Using Nigella sativa oil to treat and heal chemical induced wound of rabbit skin. JKAU. Med. Sci., 2009;21(2): 335-346.

6. Hadjzadeh MA. The effects of Nigella sativa and rheum ribes on cisplatin induced renal failure in rat. MUMS, Mashhad, Iran,1984.(Mashhad Uni. Of Med. Sci.)

7. Gerige SJ, Gerige MKY, Rao M and Raman j. GC-MS analysis of Nigella sativa seeds and antimicrobial activity of its volatile oil. Brazilian Archives of Biology and Technology. Intern. J., 2009;52(5):11891192.

8. Musa D, Dilsiz N, Gumushan H, Ulakoglu G and Bitiren M. Antitumor activity of an ethanol extract of Nigella sativa seeds. Biologia, Bratislava, 2004;59(6):735-740.

9. Tonkal AMD. In vitro antitrichomonal effect of Nigella sativa aqueous extract and wheat germ agglutinin. JKAU. Med. Sci. 2009;16(2):17-34.

10. Odds FC. Candida and candidosis. Baillie're Tindall, London 1988:460.

11. Atai Z, Atapour $M$ and Mohseni $M$. Inhibitory effect of ginger extract on Candida albicans. American Journal of Applied Sciences, 2009, 6 (6), 1067-1069.

12. Scalabrini str., Candida albicans FEP for nucleic acid amplification of Candida albicans DNA and Fluorescence detection with End Point analysis (FEP). Aladin, Italy. Sacace Biotechnologies Srl. Biotecnology1520.

13. Riose JL, Recio MC and Villar A. Antimicrobial activity of selected plant employed in the Spanish Mediterranean area. Journal Ethnopharmacology, 1987;21:139152.

14. Grand A, Woudergem PA, Verpoortes R and Pousset JL. Anti infections phytotherapies of 
Tree savannah of Senegal (West Africa), II Antimicrobial activity of 33 species. Journal Ethnopharmacol. 1988;22:25-31.

15. Hannan A, Saleem S, Chaudhary S, Barkaat MMU. Antibacterial activity of Nigella sativa against clinical isolates of methicillin resistant Staphylococcus aureus. Journal Ayub Med. Coll. Abbottabad, 2008;20(3).

16. P.V.T.C. Bacteriology Virology Tissue Cultures. Biomerieux Laboratory Reagents and Products. 1979:55.

17. WHO. Basic Laboratory methods in Medical Parasitology .WHO, Geneva,1991:1-90.

18. Tatfeng YM, Agba MI, Nwobu GO and Agbonlahor DE. Candida albicans in urinary tract or in seminal sac. Online J Health Allied S cs. 2003; 4: 5

19. Fabry W, Schmid EN, Schraps $M$ and Ansorg R. Isolation and purification of chlamydospores of Candida albicans. Medical mycology, 2003; 41:53-58.

20. Kwon Chung KJ, Bennett JE. Candidiasis. Medical Mycology (Lea and Febigered), Philadelphia,1992;13:280-336

21. Al-Assaaf SJ. Study of the inhibitory effect of some medicinal plants extracts on some pathogenic fungi. Thesis.2008:90-99.

22. Verpoort R, Tginastoi A, Vandoorne $H$ and Svendsen AB. Medicinal plant of Surinam. 1Antimicrobial activity of some medicinal plants. J. Ethanoph. 1982;5:221-226.

23. El Wakil HS. Evaluation of the in vitro effect of Nigella sativa aqueous extract on Blastocystis hominis isolates. J. Egypt Soc. Parasitol. 2007; 37(3): 801-813.

24. Al-Heali FM, Rahemo Z. The combined effect of two aqueous extracts on the growth of Trichomonas vaginalis in vitro. Turkiye Parazitol. Derg. 2006; 30(4): 272-274.

25. Rashan IJ, Abed AA. and Aziz A. Further observation of the pharmacological activities of the aqueous extract of Aristolochia bottae stems. Fitoloerapial XIII, 1992;4:350-352.

26. Nakamoto, S.,Promotion of chlamydoconidium formation in Candida albicans by corn meal broth incubation. Med. Mycol.1998;36:123-125.
27. Hanafy MSM and Hatem ME. Studies on the antimicrobial activity of Nigella sativa seed (black cumin). $\mathrm{J}$ of Ethnopharmacol. 1991;34(2-3):275-278.

28. Haq A, Lobob PI, Al-Tufailc M, Ramaa NR, and Al-Sedairya ST. Immunomodulatory effect of Nigella sativa proteins fractionated by ion exchange chromatography. Int. J. Immunopharmacol. 1999; 21: 283-295 